\title{
Ontogenetic skull variation in an Amazonian population of lowland tapir, Tapirus terrestris (Mammalia: Perissodactyla) in the department of Loreto, Peru
}

\author{
Rommel R. ROJAS ${ }^{1 *}$, , Walter Vasquez MORA ${ }^{1}$, Ethersi Pezo LOZANO${ }^{1}$, Emérita R. Tirado HERRERA ${ }^{1}$, \\ Eckhard W. HEYMANN² ${ }^{2}$ Richard BODMER ${ }^{3}$ \\ 'Universidad Nacional de la Amazonía Peruana-UNAP, Facultad de Ciencias Biológicas-FCB, Museo de Zoología, Iquitos, Loreto, Peru \\ ${ }^{2}$ Deutsches Primatenzentrum, Leibniz-Institut für Primatenforschung, Abteilung Verhaltensökologie \& Soziobiologie, Göttingen, Germany \\ ${ }^{3}$ Museo de las culturas indígenas de la Amazonia, Fundamazonia, 332 Malecón Tarapacá, lquitos, Loreto, Peru \\ ${ }^{*}$ Corresponding author: rrojaszamora@gmail.com; (D) https://orcid.org/0000-0003-3154-8549
}

\begin{abstract}
The skulls of 54 specimens of the South American tapir, Tapirus terrestris collected in the department of Loreto, Peru were measured, analyzed and compared to investigate skull development of this species. Univariate, multivariate and allometric analyses were performed using 32 skull variables through traditional morphometrics. Significant skull shape variation was detected among ontogenetic classes. Young individuals (class $\mathrm{I}, \mathrm{n}=22$ ) showed higher variation than subadults and adults (class II, $\mathrm{n}=23$ and class III, $\mathrm{n}=9$ ), without evidence of sexual dimorphism (males = 35, females = 19). Principal component analyses and discriminant function analysis showed almost complete separation of the age classes. Allometric analysis indicated a tendency of unproportioned cranial growth. All our samples come from the same population living under the same ecological condition, which eliminates the effect of confounding variables related to habitat on the pattern of ontogenetic variation of this anatomical structure.
\end{abstract}

KEYWORDS: Amazonia; morphology; skull; tapir, ontogeny

\section{Variación ontogenética de cráneos en una población amazónica del tapir sudamericano, Tapirus terrestris (Mammalia: Perissodactyla) en Loreto, Perú}

\section{RESUMEN}

Se midió, analizó y comparó 54 cráneos de tapir sudamericano, Tapirus terrestris recolectados en el departamento de Loreto, Perú, para investigar el desarrollo craneal de esta especie. Se realizaron análisis univariados, multivariados y alométricos de los cráneos utilizando 32 variables mediante morfometría tradicional. Se detectó una variación significativa de la forma del cráneo entre clases ontogenéticas. Los individuos más jóvenes (clase I, n = 22) mostraron mayor variación que subadultos y adultos (clases II, $\mathrm{n}=23$ y III, $\mathrm{n}=9$ ), pero sin evidencia de dimorfismo sexual (machos $=35$, hembras $=19$ ). Un análisis de componentes principales y un análisis de función discriminante mostraron una separación casi completa de las clases ontogenéticas. El análisis alométrico indicó una tendencia de crecimiento craneal desproporcionado. Todas nuestras muestras provienen de la misma población que vive bajo la misma condición ecológica, lo que elimina el efecto de confusión de variables relacionadas con el hábitat sobre el patrón de variaciones ontogenéticas de esta estructura anatómica.

PALABRAS CLAVE: Amazonía, morfología, cráneo, tapir, ontogenia

\section{INTRODUCTION}

The ungulate mammal genus Tapirus Brisson, 1762 (Perissodactyla), comprises five living species: T. pinchaque (Roulin, 1829) distributed in the Andes mountains, T. terrestris (Linnaeus, 1758) and T. kabomani (Cozzuol et al. 2013) in South American Amazonia; T. bairdii (Gill, 1865) in Central America and T. indicus Desmarest, 1819 in southeastern Asia. South American species of tapirs dispersed from North America during the Great American Biotic Interchange, which followed the formation of the Isthmus of Panama (Webb 1991; Woodburne 2010; Carrillo et al. 2014; O'Dea et al. 2016). All tapirs have rounded, protruding rumps with stubby tails, oval, white-tipped ears and splayed, hooved toes, with four toes on the front feet and three on the hind feet; females have a single pair of mammary glands and 
males have long penises relative to their body size (Bodmer $e t$ al. 1988; Maffei 2003). The most prominent feature of their head morphology is the presence of a short, mobile proboscis (Padilla and Dowler 1994).

Cranial characters are highly diagnostic in mammals and skulls are the most common skeletal structures preserved in museum collections (Pagels and Blem 1984; Janis 1990; Thomason 1991; Cooper and Purvis 2009; Figueirido et al. 2011; Dumbá et al. 2019). Cranial measurements combined with traditional morphometrics are useful tools for the description and statistical analysis of many biological questions related to growth, development and allometry (Gould 1966, 1980; Alberch et al. 1979; Rohlf and Slice 1990; Klingenberg 1996). Morphological variations related to sex and age are widely used to find phenotypic differences between and within populations linked to trophic adaptations that allow to avoid competition between sexes or age groups (Russel 1985; Rohlf 1998; Breno et al. 2011; Zatoń-Dobrowolska et al. 2017; Dumbá et al. 2019; Mandarim-De-Lacerda 2019).

Skull morphometry presents high levels of differentiation among species in the genus Tapirus (Dumbá et al. 2019). It has been suggested that the skull structure of $T$. terrestris is largely conserved throughout the postnatal ontogeny (Moyano and Giannini 2017), but this study was based on skulls collected over the entire geographic range of $T$. terrestris. Our study investigates the skull development in T. terrestris using a large sample of skulls from the same population in Amazonia, with the aim of controlling the effect of ecological conditions on the ontogenetic and sexual dimorphism of the South American tapir.

\section{MATERIAL AND METHODS}

\section{Study area}

Skulls of T. terrestris were collected by subsistence hunters in the Tamshiyacu Tahuayo Regional Community Conservation Area (4.201 km²; $\left.4^{\circ} 17^{\prime} 37^{\prime \prime S}, 73^{\circ} 14^{\prime} 10^{\prime \prime W}\right)$ (Figure 1) over ten years (1980-1990) as part of a participatory study on the impacts of hunting. Sex of specimens were obtained by two authors (E. Pezo and R. Bodmer) through anatomical visual inspection of specimens during field study. The collection sites were in tierra firme forests (75\%) and floodplain forests (25\%) (Bodmer et al. 2000). There are large expanses of Mauritia flexuosa palm swamps in the collected area, which produce a fruit favored by the tapir (Bodmer 1990). A more complete description of the habitats in the study area can be found in Pitman (2003).

\section{Morphometric data}

We examined 54 skulls ( 35 males and 19 females) deposited in the zoological collection of Museo de Zoología de la Universidad Nacional de la Amazonía Peruana - MZUNAP (Supplementary Material, Table S1).

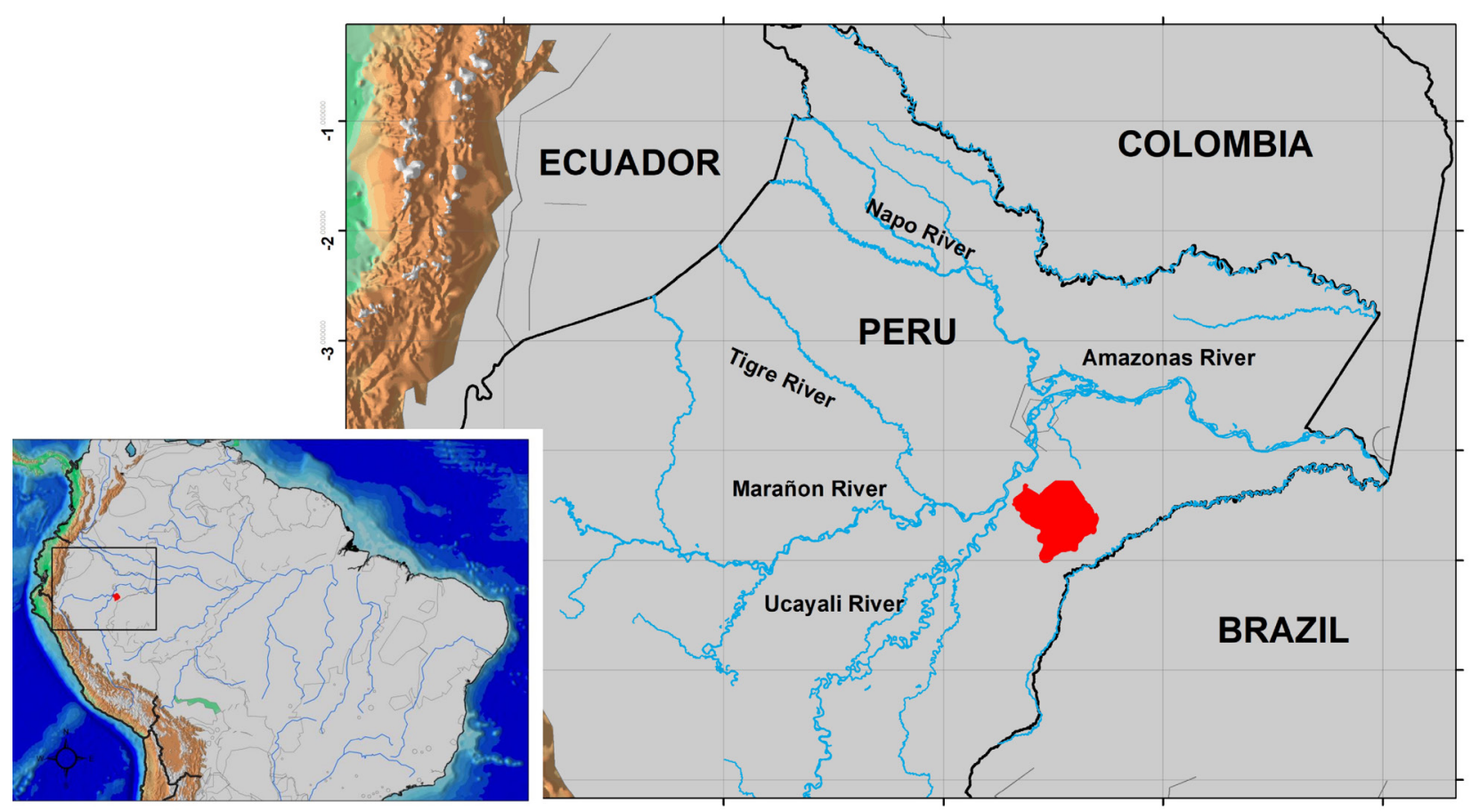

Figure 1. Location of the Tamshiyacu Tahuayo Regional Community Conservation Area (in red) in Loreto, Peru. The total area of geographic distribution of Tapirus terrestris is marked in (gray) (IUCN 2021). This figure is in color in the electronic version. 
We took 32 measurements from each skull with a manual caliper following Castañeda et al. (2016) (Figure 2; Table $1)$. We grouped the specimens into age classes following the dental eruption key by Gibson (2011), which is based on a population of Baird's tapir (Tapirus bairdii) from the Osa Peninsula in Costa Rica. We assumed that the values determined for T. bairdii are similar to those of T. terrestris. We examined the upper dentition and classified the specimens into three age classes following Moyano and Giannini (2017) with modifications by us (Figure 3):
- Class I (young juvenile, $\mathrm{n}=22$ ): molar 1 fully erupted, molar 2 and molar 3 not erupted;

- Class II (subadult to young adult, $\mathrm{n}=23$ ): molar 1 and 2 erupted, molar 3 not erupted;

- Class III (adult to old adult, $\mathrm{n}=9$ ): all dental elements fully erupted.

Class I comprised individuals under one year of age, Class II individuals between 1 and 6 years, and Class III individuals older than 6 years (see Gibson 2011).

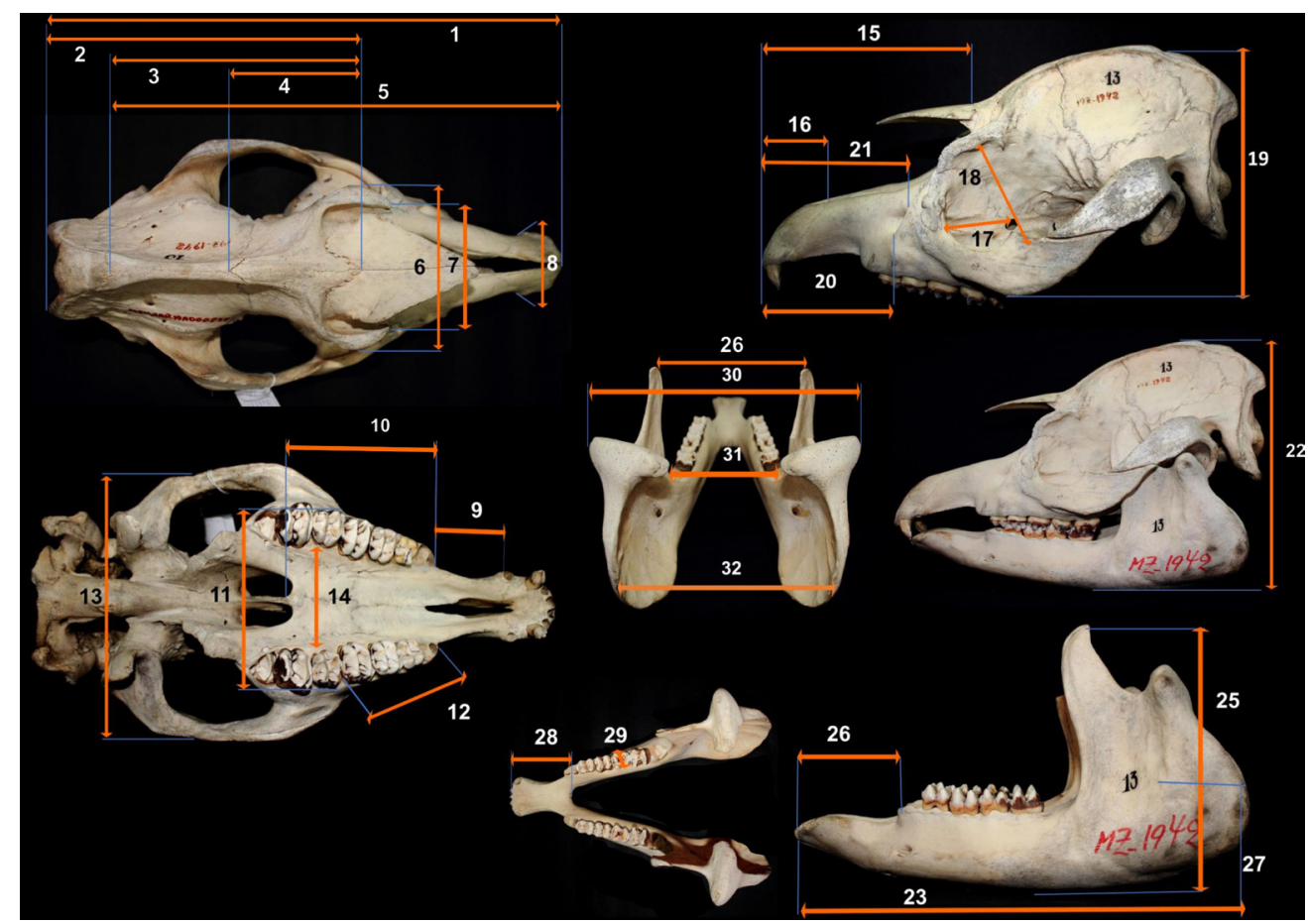

Figure 2. Skull measurements of Tapirus terrestris used in this study. Numbers correspond to Table 1. Credit: Abel GómezVasquez. This figure is in color in the electronic version.

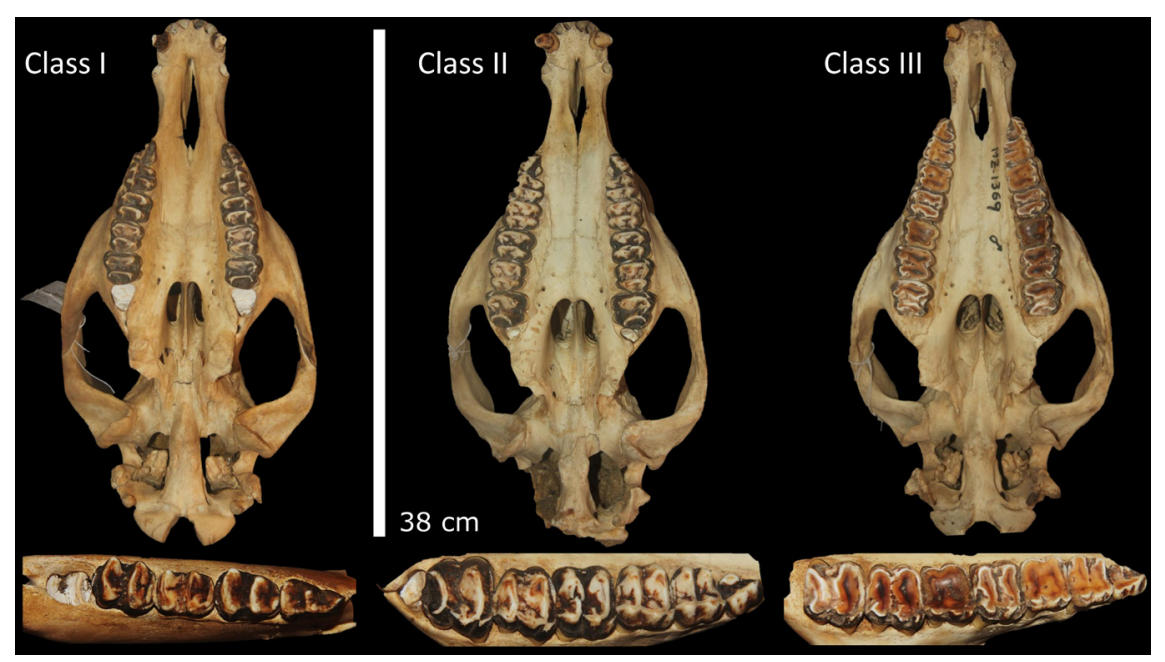

Figure 3. Skull of Tapirus terrestris in ventral view representing the three age classes used in this study. A - Class I (MZUNAP-MA 202); B - Class II (MZUNAP-MA 120); C - Class III (MZUNAP-MA 225). This figure is in color in the electronic version. 
Table 1. List of morphological measurements of the skull of Tapirus terrestris used in this study. Numbers correspond to the measurements in Figure 2.

\begin{tabular}{|c|c|c|}
\hline $\mathrm{Nr}$ & Variable & Description \\
\hline \multicolumn{3}{|c|}{ Dorsal view of skull } \\
\hline 1 & TLS & Total length of the skull, from the cranial tip of the incisor bones to the caudal level of the neckline \\
\hline 2 & LSFNS & Length of the frontonasal suture \\
\hline 3 & FNSL_POS_SC & Frontonasal suture length to parietal-occipital suture of sagittal crest \\
\hline 4 & FSL_FPS_SC & Frontonasal suture length to the frontal parietal suture of the sagittal crest \\
\hline 5 & POSL_SCP & Parietal-occipital suture length from sagittal crest to prosthion \\
\hline 6 & GWBO & Greater width between orbits \\
\hline 7 & MWBO & Minimum width between orbits \\
\hline 8 & GWP_IC & Greater width of the premaxilla between incisors and canines \\
\hline \multicolumn{3}{|c|}{ Ventral view of skull } \\
\hline 9 & P_P & Premolar - Prosthion \\
\hline 10 & $\mathrm{PL}$ & Palatal Length \\
\hline 11 & WP_BM1 & Width of Palate at beginning of Molar 1 \\
\hline 12 & LRP & Length of row of premolars \\
\hline 13 & ZW & Zygomatic width \\
\hline 14 & ID_PM1 & Internal distance from palate to molar 1 \\
\hline \multicolumn{3}{|c|}{ Lateral view of skull } \\
\hline 15 & $\mathrm{VCL}$ & Visceral cranial length \\
\hline 16 & PLL & Premaxillary Lateral Length \\
\hline 17 & GILO & Greater internal longitude of the orbit \\
\hline 18 & GIWO & Greater inner width of the orbit \\
\hline 19 & CHWM & Cranial height without mandibule \\
\hline 20 & HIOF & Height of the infraorbital foramen \\
\hline 21 & IFTS & Infraorbital foramen at the tip of the skull \\
\hline \multicolumn{3}{|c|}{ Cranial-mandibular view } \\
\hline 22 & $\mathrm{SH}$ & Skull Height \\
\hline \multicolumn{3}{|c|}{ Lateral view of the jaw } \\
\hline 23 & $\mathrm{ML}$ & Mandibular Length \\
\hline 24 & LD & Length of diastema \\
\hline \multicolumn{3}{|c|}{ Medial jaw view } \\
\hline 25 & $\mathrm{MMH}$ & Maximum mandibular height \\
\hline 26 & MHCP & Maximum Height of the condylar process \\
\hline 27 & MF_CEM & Mandibular foramen to the caudal edge of the mandible \\
\hline \multicolumn{3}{|c|}{ Dorsal jaw view } \\
\hline 28 & MLS & Mandibular length (symphysis) \\
\hline 29 & MTM1 & Mandibular thickness in molar 1 \\
\hline \multicolumn{3}{|c|}{ Caudal jaw view } \\
\hline 30 & ECA & External condylar amplitude \\
\hline 31 & ICW & Internal condylar width \\
\hline 32 & MWMC & Medial width of mandibular crest \\
\hline
\end{tabular}

\section{Morphometric analysis}

The effect of cranial length was removed from all variables by regressing the measurement on skull length and using the residuals in a Principal Component Analysis (PCA). The morphometric variables were compared between sexes and among age classes with linear model analysis with the two first principal component scores as dependent variables and age class and sex as the independent variables. The first two principal components were used because they explained the majority of the observed variance in shape by sex and age class. A Discriminant Function Analysis (DFA) was performed using the same free-size data set to test the classification of individuals in the predicted groups. Thus, the PCA was used to detect groups and the DFA was subsequently applied to identify the set of characters that best diagnose those groups. All the statistical analysis were performed in $\mathrm{R}(\mathrm{R}$ Development Core Team 2011) using the standard packages ggplot 2 (Wickham 2016), ggpurb (Kassambara 2020), coefplot (Lander 2018), adopting a 0.05 significance cut-off. (Supplementary Material, Table S2 and Appendix S1). 


\section{Allometry}

To determine the relative changes of each parameter, the allometric equation determined by Huxley (1932): $\log (y)=$ $\log (\mathrm{a})+\mathrm{b} \log (\mathrm{x})$. We considered the total length of the skull (x) as the base independent variable, whereas the other measures (y) were added to the regression. An analysis of covariance was used to test for differences in allometric patterns between age classes for all traits.

For a given variable, allometry is a deviation of its corresponding eigenvector element with respect to a hypothetical isometric value that represents isometry of all variables. The expected isometric value is calculated as the square root of $1 / \mathrm{p}$ with $\mathrm{p}$ equal to the number of variables. In our study the hypothetical isometric value was 0.182 for 32 skull variables.

\section{RESULTS}

\section{Sexual dimorphism and ontogenetic variation}

The first two principal components extracted by the PCA accounted for $69.7 \%$ of the variation in the dataset. The first component (PC1) explained $62.6 \%$ of total variance, the second component (PC2) explained 7.1\% (see Supplementary Material, Table S3 for character loadings, eigenvalues, and percentage of explained variance for $\mathrm{PC} 1$ and $\mathrm{PC} 2$ ).
The linear model analysis suggested non-significant differences in skull shape between sexes but significant differences between Class I vs. Class II and III, but not between Class II and Class III. The two axes of the PCA indicate a high overlap in relative skull shape between the sexes (Figure 4A). As no sexual dimorphism was detected, male and female data were pooled for morphometric analyses of age classes. The DFA classified $100 \%$ of the skulls into the correct sex, with moderate prior group probabilities (females $=35 \%$, males $=64 \%$ ) (Figure 5). The variables that contributed most to the classification were POSL_SCP, WP_BM1, FSL_FPS_ SC, MTM1 and HIOF (Supplementary Material, Table S3).

The comparative analysis of the quantitative PCA data allowed us to distinguish the three age classes. In the first PCA axis, specimens of class I shared relative shape with class II. In the second axis, the specimens of class I shared relative shape with classes II and III (Figure 4B). The DFA correctly classified $78.6 \%$ of the skulls, with a moderate prior probability of groups (class I $=40 \%$, class II $=42 \%$, class III $=16 \%)$ (Figure 6). The variables that contributed most to the classification were MTM1, FNSL_POS_SC, ML, HIOF, VCL and ID_PM1 (Supplementary Material, Table S3). The descriptive statistics of each measurement and significance values are in Table 2 .
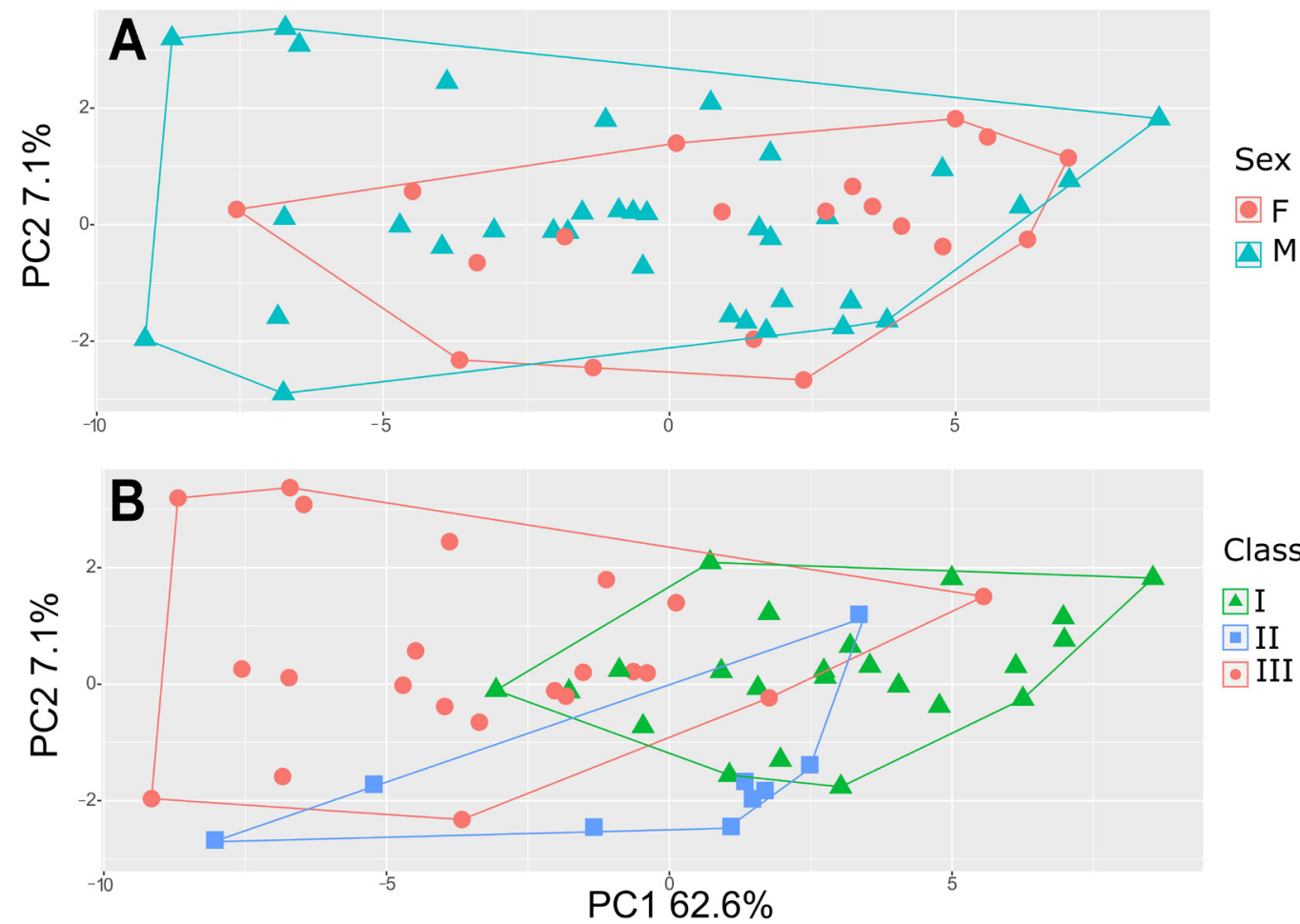

Figure 4. Principal component analysis (PCA) of skull morphometric variables of Tapirus terrestris from Loreto, Peru. A - between sexes (35 males and 19 females); and $B$ - among age classes (class I: $n=22$; class $11: n=23$; class $I I I: n=9$ ). This figure is in color in the electronic version. 

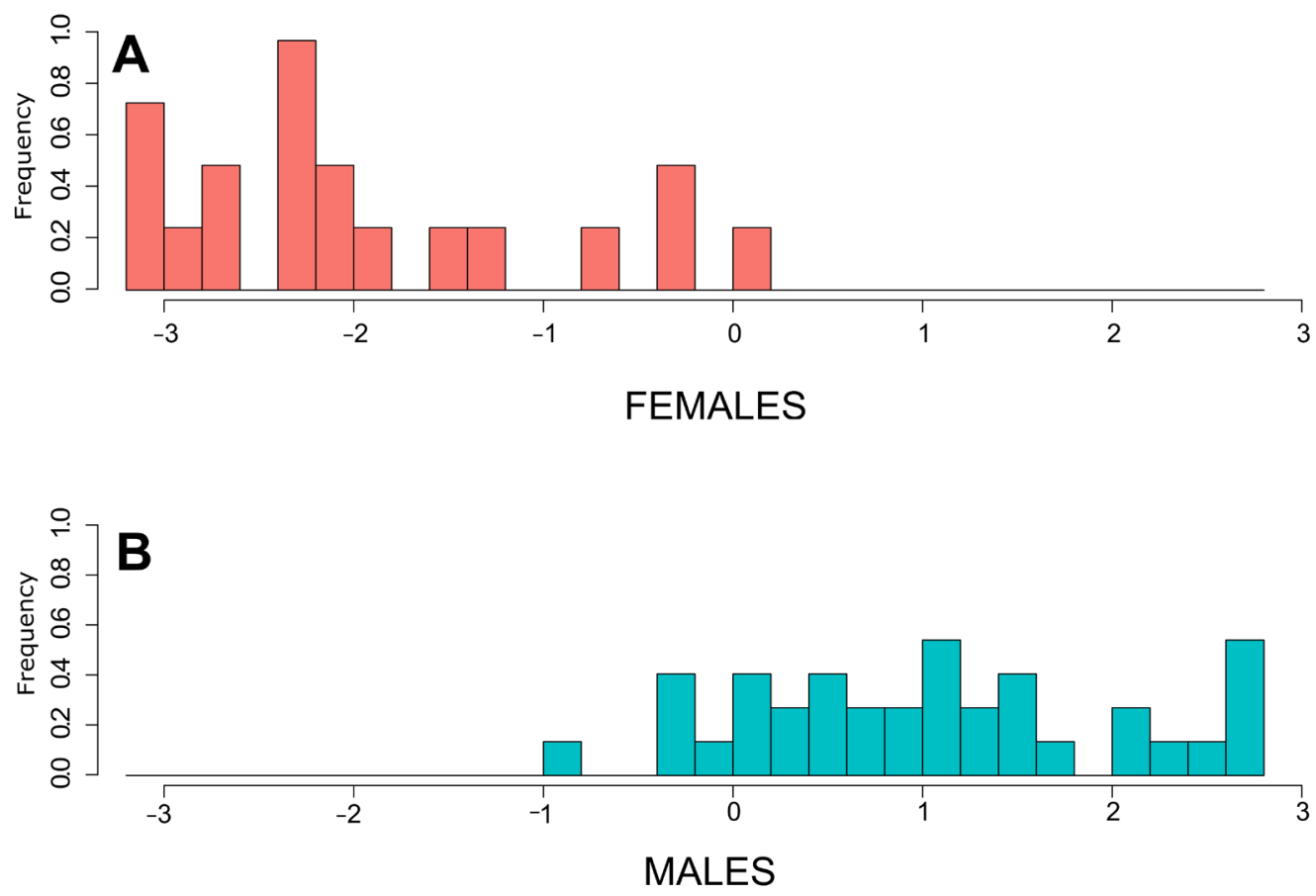

Figure 5. Linear discriminant (LD1) histograms of the discriminant function analysis for morphometric variables of skulls of Tapirus terrestris from Loreto, Peru between sexes. A - females; B - males. This figure is in color in the electronic version.
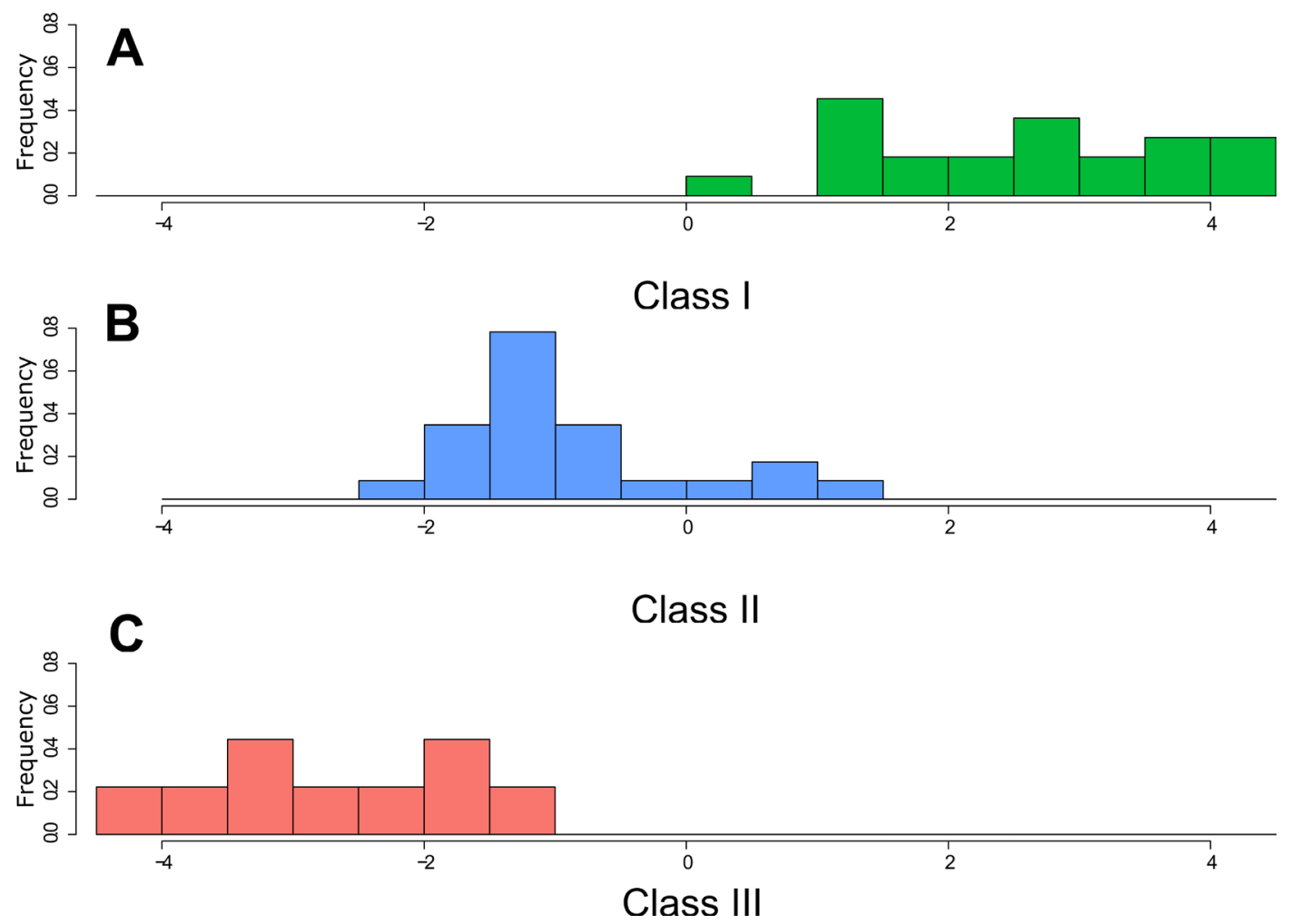

Figure 6. Linear discriminant (LD1) histograms of the discriminant function analysis for morphometric variables of skulls of Tapirus terrestris from Loreto, Peru among age classes. A - Class I; B - Class II; C - Class III. This figure is in color in the electronic version. 
Table 2. Descriptive statistics of skull measurements of Tapirus terrestris from Loreto (Peru) for each of three age classes. $\min =$ minimum value; $\max =\operatorname{maximum}$ value; $\mathrm{me}=$ median; $\mathrm{me}=$ mean; $\mathrm{sd}=$ standard deviation; $\mathrm{cv}=$ coefficient of variation; $\mathrm{var}=$ variance. ${ }^{*}$ Indicates significant differences among age classes at $\mathrm{p} \leq 0.05$. All measurements are in $\mathrm{cm}$. Variable acronym correspondence as in Table 1.

\begin{tabular}{|c|c|c|c|c|c|c|c|c|}
\hline Variable & Class & $\mathrm{n}$ & $\min$ & $\max$ & me & $s d$ & $\mathrm{cv}$ & var \\
\hline \multirow{3}{*}{ TLS* } & 1 & 22 & 33.90 & 39.40 & 36.25 & 1.48 & 0.04 & 2.20 \\
\hline & $\|$ & 23 & 36.70 & 40.50 & 38.67 & 1.06 & 0.03 & 1.13 \\
\hline & III & 9 & 35.30 & 39.70 & 38.37 & 1.29 & 0.03 & 1.67 \\
\hline \multirow{3}{*}{ LSFNS* } & 1 & 22 & 16.70 & 21.40 & 18.83 & 1.06 & 0.06 & 1.13 \\
\hline & $\|$ & 23 & 18.50 & 22.10 & 20.03 & 0.94 & 0.05 & 0.89 \\
\hline & III & 9 & 17.70 & 20.60 & 19.37 & 0.93 & 0.05 & 0.87 \\
\hline \multirow{3}{*}{ FNSL_POS_SC } & 1 & 22 & 11.90 & 16.40 & 14.47 & 1.21 & 0.08 & 1.47 \\
\hline & $\|$ & 23 & 13.60 & 16.80 & 15.09 & 0.88 & 0.06 & 0.78 \\
\hline & III & 9 & 13.70 & 16.30 & 14.86 & 0.78 & 0.05 & 0.62 \\
\hline \multirow{3}{*}{ FSL_FPS_SC } & I & 22 & 5.90 & 9.90 & 8.05 & 0.80 & 0.10 & 0.64 \\
\hline & $\|$ & 23 & 7.40 & 9.90 & 8.41 & 0.72 & 0.09 & 0.52 \\
\hline & III & 9 & 7.60 & 8.70 & 8.09 & 0.37 & 0.05 & 0.14 \\
\hline \multirow{3}{*}{ POSL_SCP* } & 1 & 22 & 31.30 & 36.00 & 33.54 & 1.25 & 0.04 & 1.56 \\
\hline & $\|$ & 23 & 33.30 & 36.90 & 35.17 & 1.05 & 0.03 & 1.11 \\
\hline & III & 9 & 33.00 & 37.60 & 35.11 & 1.31 & 0.04 & 1.72 \\
\hline \multirow{3}{*}{ GWBO* } & 1 & 22 & 8.00 & 10.50 & 9.22 & 0.66 & 0.07 & 0.43 \\
\hline & $\|$ & 23 & 8.50 & 10.90 & 9.93 & 0.58 & 0.06 & 0.34 \\
\hline & III & 9 & 9.30 & 11.30 & 10.17 & 0.70 & 0.07 & 0.49 \\
\hline \multirow{3}{*}{ MWBO* } & 1 & 22 & 7.10 & 8.60 & 7.90 & 0.46 & 0.06 & 0.21 \\
\hline & $\|$ & 23 & 7.40 & 9.50 & 8.32 & 0.47 & 0.06 & 0.22 \\
\hline & III & 9 & 7.80 & 9.30 & 8.40 & 0.44 & 0.05 & 0.19 \\
\hline \multirow{3}{*}{ GWP_IC* } & 1 & 22 & 3.40 & 4.80 & 3.96 & 0.33 & 0.08 & 0.11 \\
\hline & $\|$ & 23 & 3.60 & 5.00 & 4.31 & 0.31 & 0.07 & 0.10 \\
\hline & III & 9 & 4.10 & 4.90 & 4.44 & 0.28 & 0.06 & 0.08 \\
\hline \multirow{3}{*}{ P_P* } & 1 & 22 & 7.40 & 9.70 & 8.44 & 0.65 & 0.08 & 0.42 \\
\hline & $\|$ & 23 & 7.80 & 9.40 & 8.75 & 0.48 & 0.05 & 0.23 \\
\hline & III & 9 & 6.60 & 9.00 & 8.16 & 0.78 & 0.10 & 0.61 \\
\hline \multirow{3}{*}{$P L$} & 1 & 22 & 16.00 & 19.30 & 17.79 & 1.07 & 0.06 & 1.11 \\
\hline & $\|$ & 23 & 17.80 & 20.50 & 19.19 & 0.71 & 0.04 & 0.51 \\
\hline & III & 9 & 17.60 & 20.90 & 19.19 & 1.05 & 0.05 & 1.15 \\
\hline \multirow{3}{*}{ WP_BM1* } & 1 & 22 & 9.00 & 10.90 & 10.17 & 0.50 & 0.05 & 0.16 \\
\hline & $\|$ & 23 & 9.70 & 11.20 & 10.53 & 0.38 & 0.04 & 0.15 \\
\hline & III & 9 & 10.00 & 11.20 & 10.60 & 0.40 & 0.04 & 0.25 \\
\hline \multirow{3}{*}{ LRP } & 1 & 22 & 7.20 & 8.50 & 7.81 & 0.34 & 0.04 & 0.09 \\
\hline & $\|$ & 23 & 7.00 & 8.10 & 7.70 & 0.32 & 0.04 & 0.10 \\
\hline & III & 9 & 7.10 & 8.10 & 7.51 & 0.31 & 0.04 & 0.12 \\
\hline \multirow{3}{*}{$\mathrm{ZW}^{*}$} & 1 & 22 & 15.40 & 18.10 & 16.81 & 0.87 & 0.05 & 0.47 \\
\hline & $\|$ & 23 & 16.60 & 18.90 & 17.71 & 0.57 & 0.03 & 0.32 \\
\hline & III & 9 & 17.00 & 19.10 & 18.04 & 0.69 & 0.04 & 0.76 \\
\hline \multirow{3}{*}{ ID_PM1* } & I & 22 & 5.10 & 6.40 & 5.61 & 0.36 & 0.06 & 0.21 \\
\hline & $\|$ & 23 & 5.60 & 7.00 & 6.10 & 0.33 & 0.05 & 0.11 \\
\hline & III & 9 & 5.30 & 6.90 & 6.09 & 0.45 & 0.07 & 0.13 \\
\hline \multirow{3}{*}{$V C L^{*}$} & 1 & 22 & 16.60 & 20.40 & 18.64 & 1.14 & 0.06 & 0.30 \\
\hline & $\|$ & 23 & 18.70 & 21.60 & 20.04 & 0.74 & 0.04 & 0.55 \\
\hline & III & 9 & 19.50 & 21.40 & 20.50 & 0.55 & 0.03 & 1.30 \\
\hline
\end{tabular}


Table 2. Continued

\begin{tabular}{|c|c|c|c|c|c|c|c|c|}
\hline Variable & Class & $n$ & $\min$ & $\max$ & me & sd & $\mathrm{cv}$ & var \\
\hline \multirow{3}{*}{ PLL } & 1 & 22 & 6.20 & 9.40 & 7.79 & 0.82 & 0.11 & 1.62 \\
\hline & $\|$ & 23 & 7.20 & 10.30 & 8.73 & 0.80 & 0.09 & 0.64 \\
\hline & III & 9 & 6.70 & 11.10 & 8.83 & 1.27 & 0.14 & 0.68 \\
\hline \multirow{3}{*}{ GILO } & I & 22 & 4.60 & 6.00 & 5.31 & 0.36 & 0.07 & 0.08 \\
\hline & $\|$ & 23 & 4.80 & 6.20 & 5.47 & 0.36 & 0.07 & 0.13 \\
\hline & III & 9 & 4.90 & 5.80 & 5.29 & 0.29 & 0.05 & 0.13 \\
\hline \multirow{3}{*}{ GIWO* } & 1 & 22 & 4.10 & 4.80 & 4.43 & 0.18 & 0.04 & 0.03 \\
\hline & $\|$ & 23 & 4.30 & 5.00 & 4.62 & 0.20 & 0.04 & 0.04 \\
\hline & III & 9 & 4.10 & 4.60 & 4.50 & 0.17 & 0.04 & 0.03 \\
\hline \multirow{3}{*}{$\mathrm{CHWM}^{*}$} & 1 & 22 & 13.30 & 16.70 & 15.09 & 0.96 & 0.06 & 0.66 \\
\hline & $\|$ & 23 & 13.40 & 17.10 & 15.76 & 0.75 & 0.05 & 0.56 \\
\hline & III & 9 & 14.90 & 17.60 & 15.90 & 0.81 & 0.05 & 0.92 \\
\hline \multirow{3}{*}{ HIOF } & 1 & 22 & 1.50 & 2.30 & 1.81 & 0.23 & 0.13 & 0.04 \\
\hline & $\|$ & 23 & 1.30 & 2.50 & 1.87 & 0.27 & 0.15 & 0.07 \\
\hline & III & 9 & 1.60 & 2.10 & 1.80 & 0.20 & 0.11 & 0.05 \\
\hline \multirow{3}{*}{$\mathrm{IFTS}^{*}$} & 1 & 22 & 10.20 & 13.20 & 11.80 & 0.80 & 0.07 & 0.31 \\
\hline & $\|$ & 23 & 11.30 & 13.30 & 12.56 & 0.50 & 0.04 & 0.25 \\
\hline & III & 9 & 11.60 & 13.70 & 12.74 & 0.55 & 0.04 & 0.63 \\
\hline \multirow{3}{*}{$S H^{*}$} & 1 & 22 & 20.00 & 25.30 & 22.86 & 1.45 & 0.06 & 1.18 \\
\hline & $\|$ & 23 & 22.40 & 26.00 & 24.27 & 1.03 & 0.04 & 1.07 \\
\hline & III & 9 & 23.50 & 27.00 & 24.70 & 1.09 & 0.04 & 2.10 \\
\hline \multirow{3}{*}{$\mathrm{ML}^{*}$} & 1 & 22 & 25.90 & 31.50 & 28.96 & 1.51 & 0.05 & 1.02 \\
\hline & $\|$ & 23 & 26.70 & 32.60 & 31.01 & 1.37 & 0.04 & 1.87 \\
\hline & III & 9 & 29.60 & 32.60 & 31.68 & 1.01 & 0.03 & 2.29 \\
\hline \multirow{3}{*}{ LD } & 1 & 22 & 4.30 & 6.90 & 5.59 & 0.58 & 0.10 & 0.50 \\
\hline & $\|$ & 23 & 5.00 & 6.60 & 5.80 & 0.46 & 0.08 & 0.21 \\
\hline & III & 9 & 3.90 & 6.00 & 5.34 & 0.71 & 0.13 & 0.34 \\
\hline \multirow{3}{*}{$\mathrm{MMH}^{*}$} & 1 & 22 & 13.60 & 18.10 & 15.86 & 1.06 & 0.07 & 0.41 \\
\hline & $\|$ & 23 & 15.00 & 18.10 & 16.65 & 0.78 & 0.05 & 0.60 \\
\hline & III & 9 & 16.30 & 18.00 & 17.00 & 0.64 & 0.04 & 1.12 \\
\hline \multirow{3}{*}{$\mathrm{MHCP} *$} & 1 & 22 & 10.00 & 13.60 & 12.22 & 0.83 & 0.07 & 0.46 \\
\hline & $\|$ & 23 & 11.40 & 14.20 & 13.26 & 0.72 & 0.05 & 0.52 \\
\hline & III & 9 & 12.40 & 14.40 & 13.32 & 0.68 & 0.05 & 0.70 \\
\hline \multirow{3}{*}{ MF_CEM } & 1 & 22 & 6.20 & 8.70 & 7.75 & 0.69 & 0.09 & 0.50 \\
\hline & $\|$ & 23 & 6.20 & 9.50 & 8.01 & 0.78 & 0.10 & 0.61 \\
\hline & III & 9 & 6.70 & 9.00 & 7.77 & 0.70 & 0.09 & 0.48 \\
\hline \multirow{3}{*}{ MLS* } & 1 & 22 & 7.10 & 9.50 & 8.11 & 0.70 & 0.09 & 0.45 \\
\hline & $\|$ & 23 & 7.80 & 9.60 & 8.64 & 0.51 & 0.06 & 0.26 \\
\hline & III & 9 & 8.00 & 10.00 & 9.08 & 0.67 & 0.07 & 0.50 \\
\hline \multirow{3}{*}{ MTM1* } & 1 & 22 & 1.80 & 3.00 & 2.22 & 0.23 & 0.10 & 0.01 \\
\hline & $\|$ & 23 & 1.90 & 2.20 & 2.08 & 0.09 & 0.04 & 0.01 \\
\hline & III & 9 & 1.80 & 2.10 & 2.00 & 0.10 & 0.05 & 0.05 \\
\hline \multirow{3}{*}{$\mathrm{ECA}^{*}$} & 1 & 22 & 14.70 & 17.90 & 16.41 & 0.83 & 0.05 & 0.54 \\
\hline & $\|$ & 23 & 15.70 & 18.60 & 17.46 & 0.73 & 0.04 & 0.53 \\
\hline & III & 9 & 16.60 & 18.60 & 17.74 & 0.73 & 0.04 & 0.68 \\
\hline \multirow{3}{*}{$\mathrm{ICW}^{*}$} & 1 & 22 & 6.60 & 8.60 & 7.39 & 0.49 & 0.07 & 0.23 \\
\hline & $\|$ & 23 & 5.80 & 8.90 & 7.68 & 0.68 & 0.09 & 0.46 \\
\hline & III & 9 & 7.20 & 8.60 & 7.96 & 0.48 & 0.06 & 0.24 \\
\hline \multirow{3}{*}{ MWMC $^{*}$} & 1 & 22 & 10.60 & 13.60 & 12.30 & 0.94 & 0.08 & 0.61 \\
\hline & $\|$ & 23 & 11.20 & 14.20 & 12.95 & 0.84 & 0.06 & 0.70 \\
\hline & III & 9 & 12.30 & 14.50 & 13.22 & 0.78 & 0.06 & 0.89 \\
\hline
\end{tabular}




\section{Allometric analysis}

The observed allometric trends were isometric in four (12.5\%) of the 32 skull measurements (FSL_FPS_SC, P_P, PLL and MF_CEM), while 11 (34.3\%) showed positive allometry (LSFNS, POSL_SCP, MWBO, PL, WP_BM1, VCL, GIWO, IFTS, HCS, MMH, ECA), and $16(53.1 \%)$ showed negative allometry (FNSL_POS_SC, GWBO, GWP_IC, LRP, ZW, ID_PM1, GILO, CH, HIOF, ML, LDbCP1, MHCP, MLS, MTM1, ICW, MWMC) (Table 3; Figure 7).

\section{DISCUSSION}

Our results demonstrate previously undocumented ontogenetic shape changes in the skull of T. terrestris whith the youngest individuals (class I) showing higher variation than subadults and adults (classes II and III). The changes were primarily related to relative differences in the growth of the facial skeleton compared to the braincase, showing that lowland tapirs follow the generalized mammalian pattern of greater relative growth of the face compared to the braincase as the animals mature (Cardini and Polly 2012). We were able to document these changes mainly because we had access to samples from a relatively restricted geographical range. In previous studies that used samples from across the entire distribution range of $T$. terrestris (Moyano and Giannini 2017), this facial growth signal was apparently obscured by regional variation. The consistency in our sample likely eliminated confounding effect of variables related to regional ecological adaptations and phylogeographic variability on ontogenetic variation, showing how sample choice can affect results of morphological analyses.

Sexual dimorphism is very common in mammals, with males usually being larger than females (Weckerly 1998; Loison et al. 1999). In the genus Tapirus, it is known that females tend to be larger than males, with no other evidence of sexual dimorphism (Bodmer et al. 1988; Padilla et al. 2010; Medici 2011). Studies using skull morphometrics to determinate sexual dimorphism in species of Tapirus are scarce. Our study is the first that report the absence of sexual dimorphism in this anatomical structure and a similar skull growth pattern between both sexes.

The ontogenetic changes reported in our study can be associated to skull development of tapirs and their ability to select specific food materials (DeSantis et al. 2020). The main

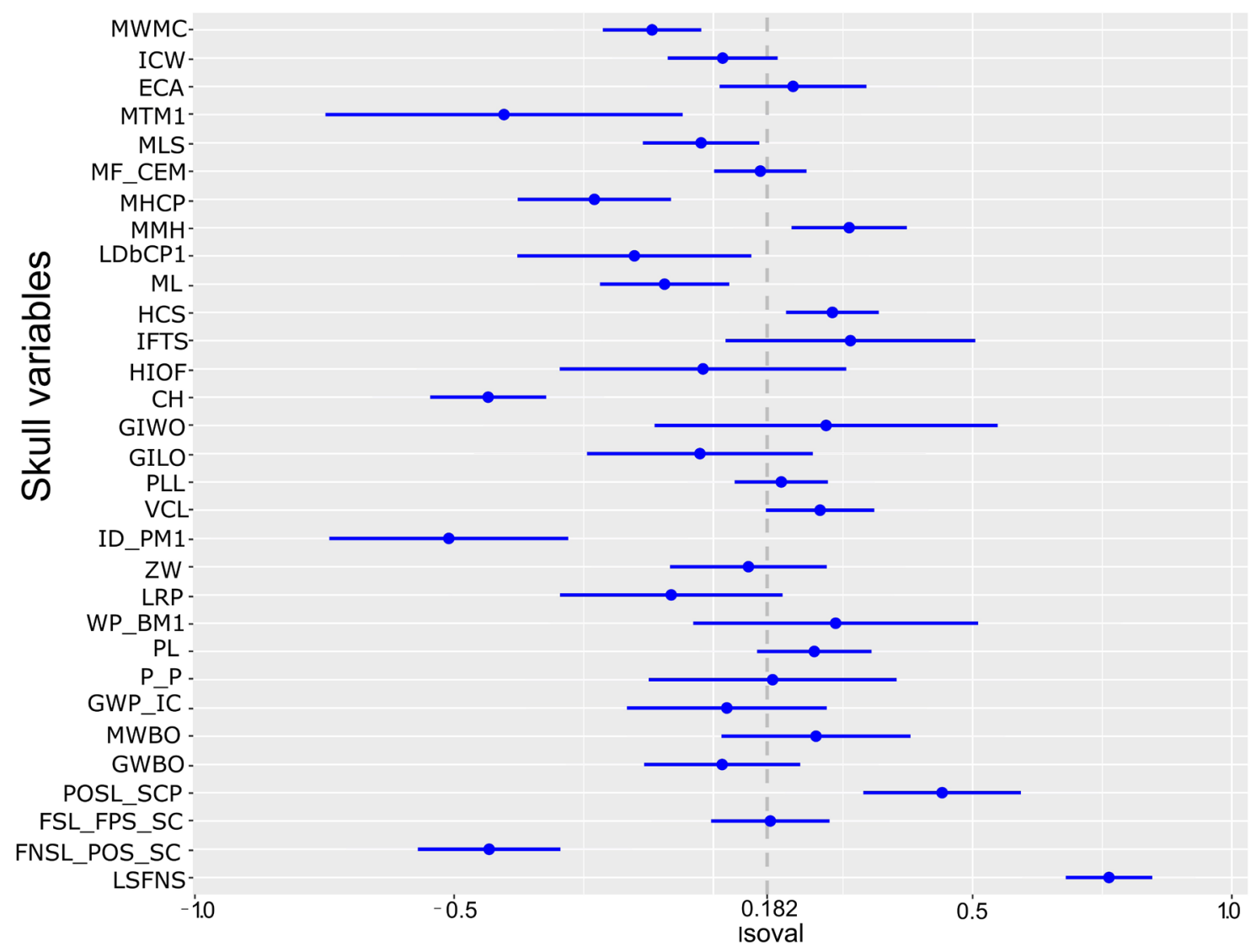

Figure 7. Distribution of confidence intervals of allometric analysis of Tapirus terrestris from Loreto, Peru relative to the isometric value (0.182). Variable acronyms as in Table 1. This figure is in color in the electronic version. 
Table 3. Allometry in cranial measurements of Tapirus terrestris from Loreto, Peru. Variables in bold indicate significant results at $\mathrm{p} \leq 0.05$. Growth trend: Iso =isometry; - = negative allometry; + = positive allometry. $\mathrm{SE}=$ standard error; $\mathrm{Cl}=$ confidence interval.

\begin{tabular}{|c|c|c|c|c|c|}
\hline Variable & Estimate & SE & t value & $\mathrm{Cl}-95 \%$ & Growth trend \\
\hline \multicolumn{6}{|l|}{ Cranium } \\
\hline LSFNS & 0.77 & 0.08 & 9.58 & $0.63-0.90$ & + \\
\hline FNSL_POS_SC & -0.42 & 0.12 & -3.30 & $-0.63--0.20$ & - \\
\hline FSL_FPS_SC & 0.07 & 0.10 & 0.71 & $-0.10-0.25$ & Iso \\
\hline POSL_SCP & 0.47 & 0.13 & 3.55 & $0.24-0.69$ & + \\
\hline GWBO & -0.06 & 0.12 & -0.49 & $-0.28-0.15$ & - \\
\hline MWBO & 0.29 & 0.16 & 1.78 & $0.01-0.57$ & + \\
\hline GWP_IC & 0.04 & 0.18 & 0.25 & $-0.27-0.36$ & - \\
\hline$P_{-} P$ & 0.11 & 0.21 & 0.51 & $-0.25-0.48$ & Iso \\
\hline$P L$ & 0.13 & 0.09 & 0.44 & $-0.02-0.28$ & + \\
\hline WP_BM1 & 0.24 & 0.24 & 1.03 & $-0.16-0.66$ & + \\
\hline LRP & -0.08 & 0.19 & -0.46 & $-0.41-0.23$ & - \\
\hline ZW & 0.11 & 0.12 & 0.98 & $-0.08-0.32$ & - \\
\hline ID_PM1 & -0.47 & 0.22 & -2.12 & $-0.85--0.09$ & - \\
\hline VCL & 0.22 & 0.10 & 2.24 & $0.05-0.39$ & + \\
\hline PLL & 0.14 & 0.08 & 1.65 & $-0.004-0.28$ & Iso \\
\hline GILO & -0.01 & 0.21 & -0.02 & $-0.36-0.35$ & - \\
\hline GIWO & 0.11 & 0.31 & 0.37 & $-0.42-0.65$ & + \\
\hline $\mathrm{CH}$ & -0.38 & 0.10 & -3.70 & $-0.56--0.20$ & - \\
\hline $\mathrm{HIOF}$ & 0.05 & 0.25 & 0.21 & $-0.38-0.49$ & - \\
\hline IFTS & 0.17 & 0.21 & 0.82 & $-0.18-0.53$ & + \\
\hline \multicolumn{6}{|l|}{ Mandible } \\
\hline $\mathrm{HCS}$ & 0.22 & 0.08 & 2.62 & $0.07-0.36$ & + \\
\hline ML & -0.08 & 0.11 & -0.75 & $-0.28-0.10$ & - \\
\hline LDbCP1 & -0.07 & 0.21 & -0.33 & $-0.43-0.29$ & - \\
\hline MMH & 0.22 & 0.10 & 2.10 & $0.04-0.39$ & + \\
\hline MHCP & -0.17 & 0.13 & -1.28 & $-0.40-0.05$ & - \\
\hline MF_CEM & 0.09 & 0.08 & 1.07 & $-0.05-0.23$ & Iso \\
\hline MLS & -0.01 & 0.10 & -0.09 & $-0.19-0.17$ & - \\
\hline MTM1 & -0.55 & 0.31 & -1.76 & $-1.09--0.01$ & - \\
\hline ECA & 0.15 & 0.14 & 1.08 & $-0.08-0.39$ & + \\
\hline ICW & 0.01 & 0.10 & 0.16 & $-0.16-0.20$ & - \\
\hline MWMC & -0.11 & 0.09 & -1.24 & $-0.28-0.04$ & - \\
\hline
\end{tabular}

negative allometric effects were observed in the mandibular bones, while positive and isometric effects were observed in cranium bones, and the variables that most contributed to skull-shape discrimination among classes were associated to the neurocranium and the splanchnocranium. The Perissodactyla exhibit a wide range of differences in cranial shape and dimensions (Dumbá et al. 2019), but the factors that drive the evolution of skull shape remain unclear (Cozzuol et al. 2013; Moyano and Giannini 2017). Our results suggest that the neurocranium and the splanchnocranium begin to differentiate slightly between subadults (class II) and adults (class III). This pattern can indicate that individuals from class II and III explore and compete for the same resources and therefore individuals of class II would be likely to disperse. 
In Tapirus, the proboscis takes over part of the foodgathering function, which in other browsers rests entirely with the anterior dentition (Erwin 2007; Chalk 2011; Moyano and Giannini 2017; Law et al. 2018). Tapirs in our study region ingested 33\% fruits, mainly the fruits of Mauritia flexuosa palm, and 66\% leaves and fiber (Bodmer 1990). The tapirs ingest the pulp of the palm fruit while the very hard seeds are not masticated but swallowed whole or spat out (Bodmer 1990). Availability and quality of food resources across different ages are likely to affect the morphology of the skull, both as a consequence of a general influence on growth rates and locally at the level of skull structure (changes in strain and loadings) (Breno et al. 2011).

\section{CONCLUSIONS}

The geographical restriction in our sample eliminated the confounding effects of geographical and ecological variability on the morphological measurements and allowed to show more clearly the ontogenetic variation in skull shape in a population of South American tapir, T. terrestris in Loreto, Perú. Our results revealed a higher variation in skull shape in juveniles than in subadults and adults, without evidence of sexual dimorphism.

\section{ACKNOWLEDGMENTS}

The authors thank the students of the Facultad de Ciencias Biológicas -FCB of the Universidad Nacional de la Amazonia Peruana (UNAP), Iquitos-Peru, that contributed to the organization, cleaning and rise of the Museo de Zoología- UNAP.

We also thank the anonymous reviewers that contributed to the improvement of the manuscript.

\section{REFERENCES}

Alberch, P.; Gould, S.J.; Oster, G.F.; Wake, D.B. 1979. Size and shape in ontogeny and phylogeny. Paleobiology, 5: 406-420.

Bodmer, R.E.; Fang, T.G.; Ibanez, L.M. 1988. Ungulate management and conservation in the Peruvian Amazon. Biological Conservation, 45: 303-310.

Bodmer, R.E. 1990. Fruit patch size and frugivory in the lowland tapir (Tapirus terrestris). Journal of Zoology, 222: 121-128.

Bodmer, R.E.; Puertas, P.; Aquino, R.; Reyes, C.J. 2000. Influence of habitat on the sustainability of mammal harvests in the Peruvian Amazon. In: Oren, D. (Ed.). Biological and Cultural Diversity of Amazonia: A World in Transformation. Museu Goeldi Press, Belém, p.385-402.

Breno, M., Leirs, H.; Van Dongen, S. 2011. Traditional and geometric morphometrics for studying skull morphology during growth in Mastomys natalensis (Rodentia: Muridae). Journal of Mammalogy, 92: 1395-1406.

Cardini, A.; Polly, D. 2013. Larger mammals have longer faces because of size-related constraints on skull form. Nature Communications, 4: 2458.
Carrillo, J.D.; Forasiepi, A.; Jaramillo, C.; Sánchez-Villagra, M.R. 2014. Neotropical mammal diversity and the great American biotic interchange: Spatial and temporal variation in South America's fossil record. Frontiers in Genetics, 5: 451. doi. org/10.3389/fgene.2014.00451

Castañeda, H.; Navarrete Z.M.; Sato S. A.; Chávez R. A. 2016. Osteometría del Cráneo de la Alpaca adulta (Vicugna pacos). Revista de Investigaciones Veterinarias del Perú, 27: 403-420.

Chalk, J. 2011. The Effects of Feeding Strategies and Food Mechanics on the Ontogeny of Masticatory Function in the Cebus libidinosus Cranium. Master thesis, Boston University, 221p. (https:// scholarspace.library.gwu.edu/etd/4m90dv67x).

Cooper, N.; Purvis, A. 2009. What factors shape rates of phenotypic evolution? A comparative study of cranial morphology of four mammalian clades. Journal of Evolutionary Biology, 22: 1024-1035.

Cozzuol, M.A.; Clozato, C.L.; Holanda, E.C.; Rodrigues, F.H.G.; Nienow, S.; de Thoisy, B.; Redondo, R.A.F.; Santos, F.R. 2013. A new species of tapir from the Amazon. Journal of Mammalogy, 94: 1331-1345.

DeSantis, L.R.G.; Sharp, A.C.; Schubert, B.W.; Colbert, M.W.; Wallace, S.C.; Grine, F.E. 2020. Clarifying relationships between cranial form and function in tapirs, with implications for the dietary ecology of early hominins. Scientific Reports, 10: 8809. doi.org/10.1038/s41598-020-65586-w

Dumbá, L.C.C.S.; Dutra, R.P.; Cozzuol, M.A. 2019. Cranial geometric morphometric analysis of the genus Tapirus (Mammalia, Perissodactyla). Journal of Mammalian Evolution, 26: 545-555.

Erwin, D.H. 2007. Disparity: Morphological pattern and developmental context. Palaeontology, 50: 57-73.

Figueirido, B.; Pérez-Claros, J.A.; Hunt, R.M.; Palmqvist, P. 2011. Body mass estimation in amphicyonid carnivoran mammals: A multiple regression approach from the skull and skeleton. Acta Palaeontologica Polonica, 56: 225-246.

Gibson, M. 2011. Population Structure Based on Age-Class Distribution of polkensis from the Gray Fossil Site Tennessee. Master's thesis, East Tennessee State University, 52p. (https://dc.etsu.edu/etd/1267).

Gould, S.J. 1966. Allometry and size in ontogeny and phylogeny. Biological reviews of the Cambridge Philosophical Society, 41: 587-640.

Gould, S. 1980. Ontogeny and Phylogeny. Harvard University Press, Cambridge, 520p.

Huxley, J. 1932. Problems of Relative Growth. Methuen and Co., London, 276p.

IUCN. 2021. The IUCN Red List of Threatened Species. Version 2021-2. (https://www.iucnredlist.org). Accessed on 20 Apr 2021.

Janis, C.M. 1990. Correlation of cranial and dental variables with dietary preferences in mammals: a comparison of macropodoids and ungulates. Memoirs of the Queensland Museum, 28: 349-366.

Kassambara, A. 2020. ggpubr: 'ggplot2' Based Publication Ready Plots. R package version 0.4.0. (https://CRAN.R-project.org/ package=ggpubr). Accessed on 15 Apr 2021.

Klingenberg, C.P. 1996. Multivariate allometry. In: Marcus L.F.; Corti M.; Loy A.; Naylor G.J.P.; Slice D.E. (Ed.). Advances in Morphometrics. Nato asi Series, Series A: Life Sciences, Ciocco, Tuscany, p.23-49. 
Lander, J.P. 2018. coefplot: Plots Coefficients from Fitted Models. $\mathrm{R}$ packages version 1.2.6. (https://CRAN.R-project.org/ package=coefplot). Accessed on 15 Apr 2021.

Law, C.J.; Duran, E.; Hung, N.; Richards, E.; Santillan, I.; Mehta, R.S. 2018. Effects of diet on cranial morphology and biting ability in musteloid mammals. Journal of Evolutionary Biology, 3: 1918-1931.

Loison, A.; Gaillard, J.M.; Pélabon, C.; Yoccoz, N.G. 1999. What factors shape sexual size dimorphism in ungulates? Evolutionary Ecology Research, 1: 611-633.

Maffei, B.L. 2003. The age structure of tapirs (Tapirus terrestris) in the Chaco. Tapir Conservation, 12: 18-19.

Mandarim-De-Lacerda, C.A. 2019. Ontogenetic and phylogenetic allometry (bivariate and multivariate) for young morphologists. International Journal of Morphology, 37: 466-472.

Medici, E.P. 2011. Family Tapiridae (tapirs). In: Wilson, D.E.; Mittermeier, R.A. (Ed.).

Handbook of the Mammals of the World. v. 2: Hoofed mammals. Lynx Edicions, Barcelona, p.182-204.

Moyano, S.R.; Giannini, N.P. 2017. Comparative cranial ontogeny of Tapirus (Mammalia: Perissodactyla: Tapiridae). Journal of Anatomy, 231: 665-682.

O’Dea, A.; Lessios, H.A.; Coates, A.G.; Eytan, R.I.; RestrepoMoreno, S.A.; Cione, A.L.; et al. 2016. Formation of the Isthmus of Panama. Science Advances, 2: e1600883.

Padilla, M.; Dowler, R.C. 1994. Tapirus terrestris. Mammalian Species, (481): 1-8. doi.org/10.2307/3504109

Padilla, M.; Dowler, R.; Downer, C. 2010. Tapirus pinchaque (Perissodactyla: Tapiridae). Mammalian Species, 42: 166-182.

Pagels, J.F.; Blem, C.R. 1984. Prediction of body weights of small mammals from skull measurements. Acta Theriologica, 29: 367-38.

R Development Core Team. 2011. R: A Language and Environment for Statistical Computing. R Foundation for Statistical Computing, Vienna. 409p.
Pitman, N. 2003. Perú: Yavari - Rapid Biological Inventory. 1st ed. The Field Museum, Chicago, 282p.

Rohlf, F.J. 1998. On applications of geometric morphometrics to studies of ontogeny and phylogeny. Systematic Biology, 47: 147-158.

Rohlf, F.J.; Slice, D. 1990. Extensions of the procrustes method for the optimal superimposition of landmarks. Systematic Zoology, 39: 40-59

Russel, L. 1985. Genetic and evolutionary aspects of allometry. In: Willian, J. (Ed.). Size and Scaling in Primate Biology. Springer, Boston, p.21-32.

Thomason, J.J. 1991. Cranial strength in relation to estimated biting forces in some mammals. Canadian Journal of Zoology, 69: 2326-2333.

Webb, S.D. 1991. Ecogeography and the Great American Interchange. Paleobiology, 17: 266-280.

Weckerly, F.W. 1998. Sexual-size dimorphism: Influence of mass and mating systems in the most dimorphic mammals. Journal of Mammalogy, 17: 266-280.

Wickham, H. 2016. ggplot2: Elegant Graphics for Data Analysis. Springer-Verlag, New York, 260p.

Woodburne, M.O. 2010. The great American biotic interchange: Dispersals, tectonics, climate, sea level and holding pens. Journal of Mammalian Evolution, 17: 245-264.

Zatoń-Dobrowolska, M.; Moska, M.; Mucha, A.; Wierzbicki, H.; Dobrowolski, M. 2017. Variation in fur farm and wild populations of the red fox, Vulpes vulpes (Carnivora: Canidae). Canadian Journal of Animal Science, 98: 84-97.

RECEIVED: 09/05/2021

ACCEPTED: 27/09/2021

ASSOCIATE EDITOR: Paulo D. Bobrowiec 


\section{SUPPLEMENTARY MATERIAL (only available in the electronic version)}

Rojas et al. Ontogenetic skull variation in an Amazonian population of lowland tapir, Tapirus terrestris (Mammalia: Perissodactyla) in the department of Loreto, Peru

Tabla S1. Collection data of Tapirus terrestris specimens from Loreto, Peru used in this study. See Material and Methods for definitions of Class.

\begin{tabular}{|c|c|c|c|c|c|}
\hline Collection code & Locality & District & Province & Sex & Class \\
\hline MZUNAP-MA000119 & Yavarí-Mirí & Yavari & Mariscal Ramon Castilla & $M$ & $\|$ \\
\hline MZUNAP-MA000203 & Corrientillo & Fernado Lores & Maynas & M & I \\
\hline MZUNAP-MA000113 & Nueva Esperanza & Yavari & Mariscal Ramon Castilla & M & $\|$ \\
\hline MZUNAP-MA000006 & Yavarí-Mirí & Yavari & Mariscal Ramon Castilla & M & III \\
\hline MZUNAP-MA000206 & Paraíso-Yavarí & Yavari & Mariscal Ramon Castilla & M & $\|$ \\
\hline MZUNAP-MA000115 & Blanco & Fernado Lores & Maynas & $\mathrm{H}$ & III \\
\hline MZUNAP-MA000120 & Paraíso-Yavarí & Yavari & Mariscal Ramon Castilla & $\mathrm{H}$ & I \\
\hline MZUNAP-MA000202 & Nueva Esperanza & Yavari & Mariscal Ramon Castilla & $\mathrm{H}$ & $\|$ \\
\hline MZUNAP-MA000008 & Nueva Esperanza & Yavari & Mariscal Ramon Castilla & $\mathrm{H}$ & III \\
\hline MZUNAP-MA000220 & San Antonio & Fernado Lores & Maynas & $\mathrm{H}$ & $\|$ \\
\hline MZUNAP-MA000213 & Carolina & Yavari & Mariscal Ramon Castilla & $\mathrm{H}$ & I \\
\hline MZUNAP-MA000214 & San Francisco & Yavari & Mariscal Ramon Castilla & M & $\|$ \\
\hline MZUNAP-MA000219 & Tamshiyacu & Fernado Lores & Maynas & M & $\|$ \\
\hline MZUNAP-MA000221 & Lemon & Fernado Lores & Maynas & M & I \\
\hline MZUNAP-MA000229 & Yavarí-Mirí & Yavari & Mariscal Ramon Castilla & M & III \\
\hline MZUNAP-MA000227 & Nueva Esperanza & Yavari & Mariscal Ramon Castilla & M & I \\
\hline MZUNAP-MA000230 & Yanayacu & Fernado Lores & Maynas & M & III \\
\hline MZUNAP-MA000236 & Yavarí-Mirí & Yavari & Mariscal Ramon Castilla & $H$ & $\|$ \\
\hline MZUNAP-MA000410 & San Francisco & Yavari & Mariscal Ramon Castilla & $\mathrm{H}$ & III \\
\hline MZUNAP-MA000407 & Cuchura & Fernado Lores & Maynas & $\mathrm{H}$ & । \\
\hline MZUNAP-MA000238 & Lemon-Blanco & Fernado Lores & Maynas & M & $\|$ \\
\hline MZUNAP-MA000237 & Corrientillo & Fernado Lores & Maynas & M & $\|$ \\
\hline MZUNAP-MA000228 & Yavarí-Mirí & Yavari & Mariscal Ramon Castilla & M & । \\
\hline MZUNAP-MA000246 & Nueva Esperanza & Yavari & Mariscal Ramon Castilla & M & $\|$ \\
\hline MZUNAP-MA000243 & San Felipe & Yavari & Mariscal Ramon Castilla & M & $\|$ \\
\hline MZUNAP-MA000245 & San José & Yavari & Mariscal Ramon Castilla & M & $\|$ \\
\hline MZUNAP-MA000247 & San Antonio & Fernado Lores & Maynas & M & $\|$ \\
\hline MZUNAP-MA000402 & Yavarí-Mirí & Yavari & Mariscal Ramon Castilla & M & III \\
\hline MZUNAP-MA000405 & Yavarí-Mirí & Yavari & Mariscal Ramon Castilla & M & । \\
\hline MZUNAP-MA000415 & Quebrada Blanca & Yavari & Mariscal Ramon Castilla & M & I \\
\hline MZUNAP-MA000421 & San Felipe & Yavari & Mariscal Ramon Castilla & M & । \\
\hline MZUNAP-MA000422 & Corrientillo & Fernado Lores & Maynas & M & । \\
\hline MZUNAP-MA000426 & Nueva Esperanza & Yavari & Mariscal Ramon Castilla & M & । \\
\hline MZUNAP-MA000427 & Yavarí-Mirí & Yavari & Mariscal Ramon Castilla & M & 1 \\
\hline MZUNAP-MA000412 & Yavarí-Mirí & Yavari & Mariscal Ramon Castilla & $H$ & $\|$ \\
\hline MZUNAP-MA000419 & San Felipe & Yavari & Mariscal Ramon Castilla & $\mathrm{H}$ & $\|$ \\
\hline MZUNAP-MA000423 & Nueva Esperanza & Yavari & Mariscal Ramon Castilla & $\mathrm{H}$ & । \\
\hline MZUNAP-MA000425 & San Felipe & Yavari & Mariscal Ramon Castilla & $H$ & $\|$ \\
\hline MZUNAP-MA000429 & Nueva Esperanza & Yavari & Mariscal Ramon Castilla & $\mathrm{H}$ & । \\
\hline MZUNAP-MA000428 & Yavarí-Mirí & Yavari & Mariscal Ramon Castilla & M & $\|$ \\
\hline MZUNAP-MA000430 & San Felipe & Yavari & Mariscal Ramon Castilla & M & । \\
\hline MZUNAP-MA000431 & Quebrada Blanca-San José & Yavari & Mariscal Ramon Castilla & M & $\|$ \\
\hline MZUNAP-MA000433 & Nueva Esperanza-Yavarí Mirí & Yavari & Mariscal Ramon Castilla & M & III \\
\hline MZUNAP-MA000434 & Yavarí-Mirí & Yavari & Mariscal Ramon Castilla & M & 1 \\
\hline MZUNAP-MA000436 & San Antonio-Tahuayo & Fernado Lores & Maynas & M & । \\
\hline MZUNAP-MA000447 & Nueva Esperanza & Yavari & Mariscal Ramon Castilla & $\mathrm{H}$ & $\|$ \\
\hline MZUNAP-MA000448 & Carolina & Yavari & Mariscal Ramon Castilla & $H$ & $\|$ \\
\hline MZUNAP-MA000446 & Corrientillo & Fernado Lores & Maynas & $H$ & $\|$ \\
\hline MZUNAP-MA000451 & Carolina & Yavari & Mariscal Ramon Castilla & $\mathrm{H}$ & I \\
\hline MZUNAP-MA000432 & RCTT & Fernado Lores & Maynas & $H$ & 1 \\
\hline MZUNAP-MA000444 & San Felipe & Yavari & Mariscal Ramon Castilla & M & । \\
\hline MZUNAP-MA000445 & Yavarí-Mirí & Yavari & Mariscal Ramon Castilla & M & $\|$ \\
\hline MZUNAP-MA000442 & San Antonio & Fernado Lores & maynas & M & III \\
\hline MZUNAP-MA000449 & Carolina & Yavari & Mariscal Ramon Castilla & M & 1 \\
\hline
\end{tabular}




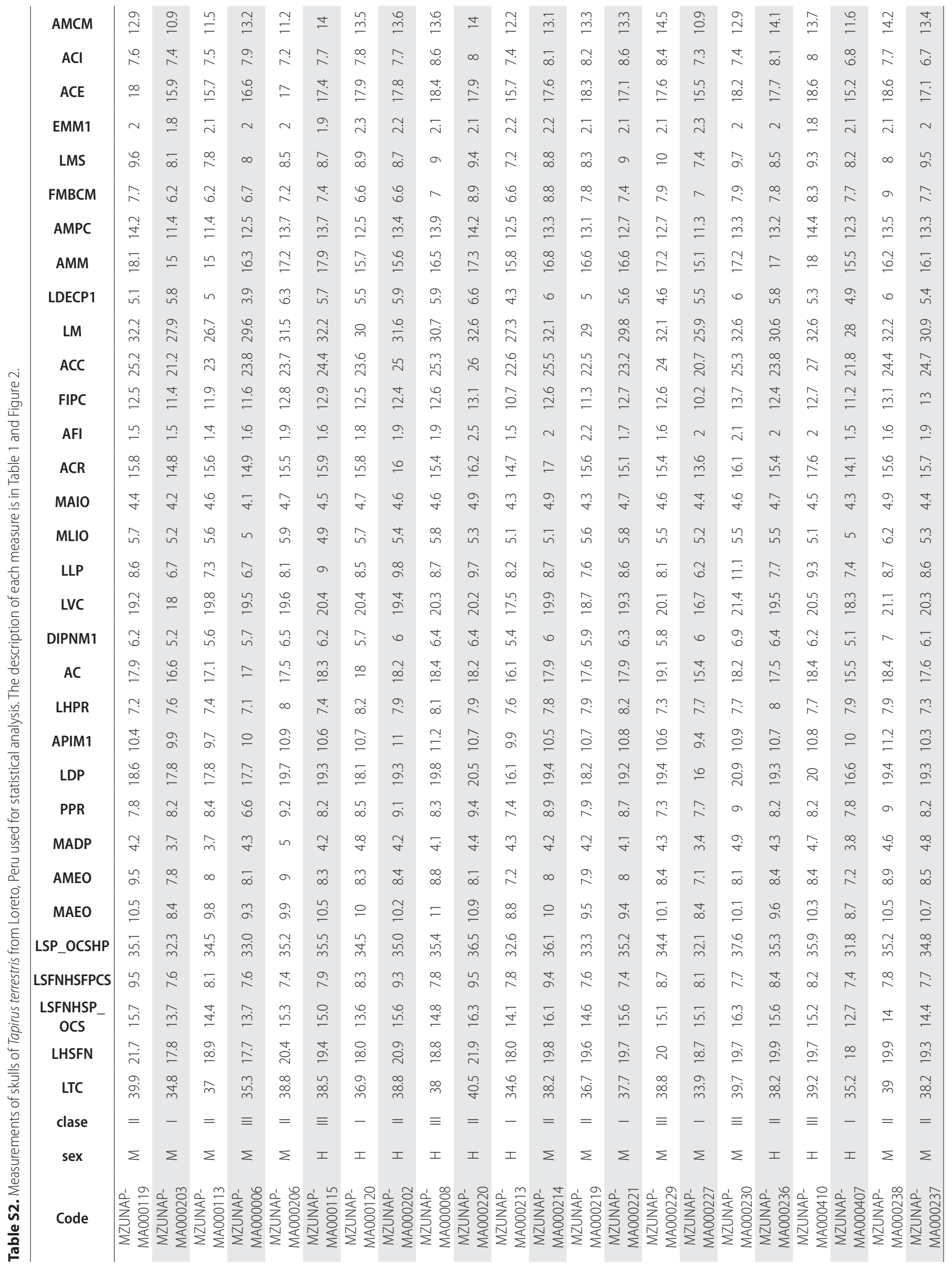




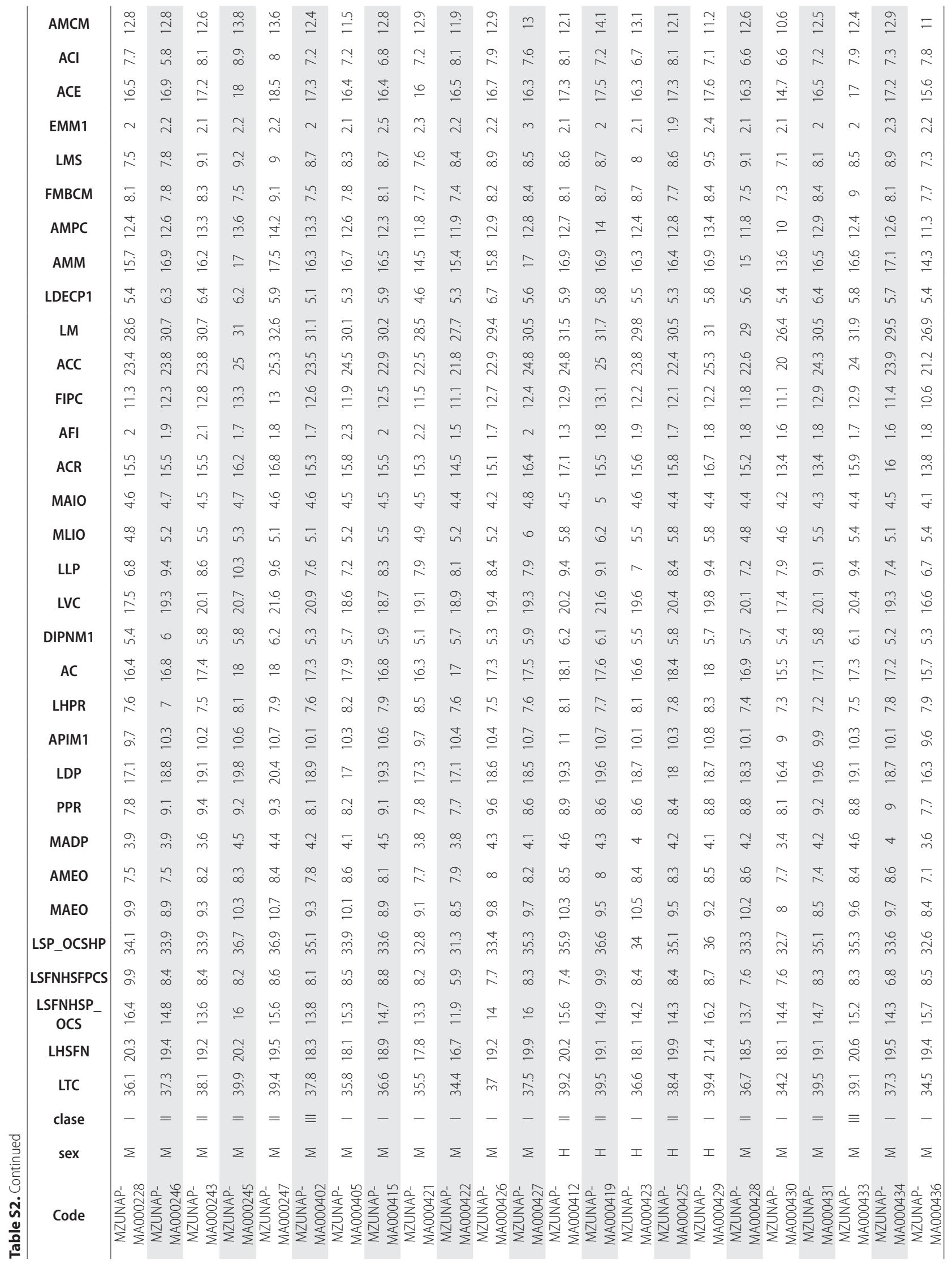




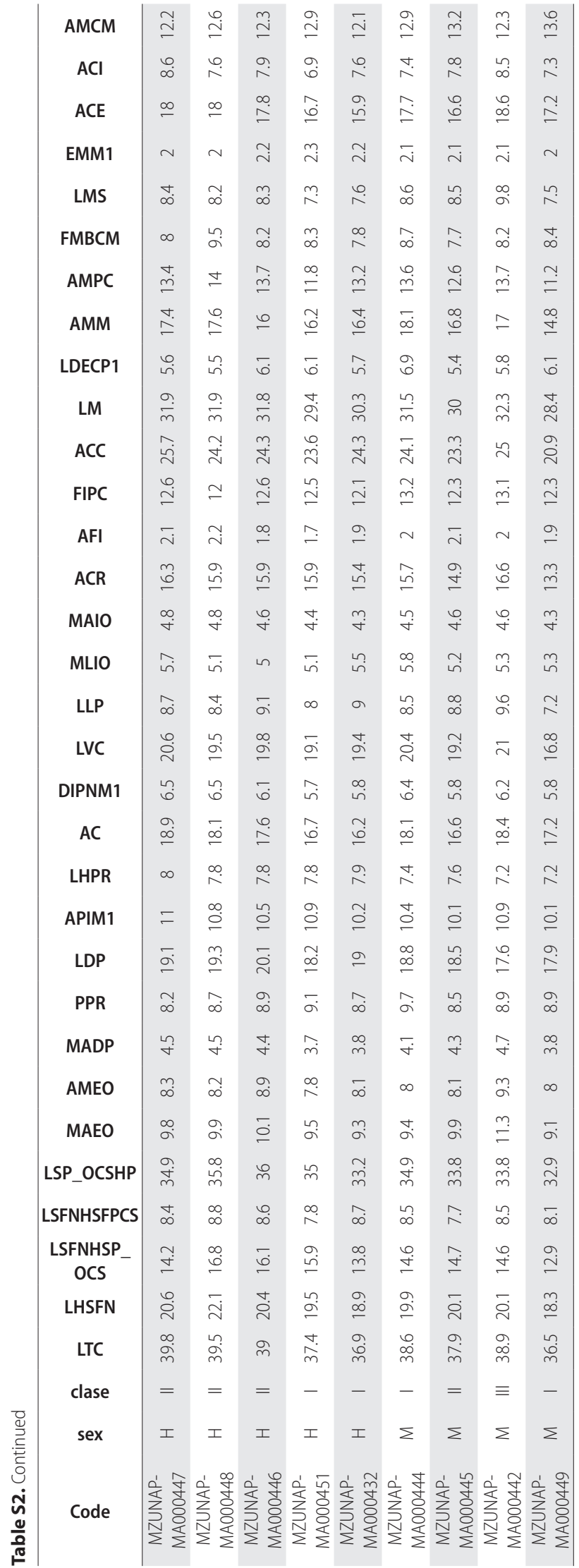

Table S3. Character loadings, eigenvalues, and percentage of explained variance for PC1 and PC2 and character loadings of explained variance for discriminant function analysis (DFA) between sexes and age classes in one population of Tapirus terrestris from Loreto, Peru. In bold are the variables that most contributed to the discrimination by sex and class.

\begin{tabular}{|c|c|c|c|c|}
\hline Variables & PC1 & PC2 & $\begin{array}{l}\text { Discriminant } \\
\text { function -sex }\end{array}$ & $\begin{array}{c}\text { Discriminant } \\
\text { function -classes }\end{array}$ \\
\hline LSFNS & 0.133 & -0.418 & -1.0859 & 0.082132474 \\
\hline FNSL_POS_SC & 0.190 & -0.263 & 1.8988 & -2.680867569 \\
\hline FSL_FPS_SC & 0.200 & -0.204 & -0.6469 & 1.333302555 \\
\hline POSL_SCP & 0.123 & -0.040 & -1.2685 & 2.268403683 \\
\hline GWBO & 0.190 & 0.096 & 0.2249 & 0.654518132 \\
\hline MWBO & 0.191 & 0.046 & -0.2732 & 0.121056639 \\
\hline GWP_IC & 0.186 & 0.115 & -0.1204 & -0.015495093 \\
\hline$P_{-} P$ & 0.185 & -0.192 & -0.3096 & -1.321557959 \\
\hline$P L$ & 0.135 & 0.151 & 0.0823 & -0.18820917 \\
\hline WP_BM1 & 0.187 & 0.144 & -0.3320 & 2.458063571 \\
\hline LRP & 0.219 & -0.135 & -3.7504 & -1.09681079 \\
\hline ZW & 0.163 & 0.226 & -0.5520 & -0.204340608 \\
\hline ID_PM1 & 0.181 & -0.028 & 0.6491 & -0.409336543 \\
\hline $\mathrm{VCL}$ & 0.156 & 0.283 & 0.9626 & -0.181388324 \\
\hline PLL & 0.152 & 0.002 & -0.2037 & 0.540287762 \\
\hline GILO & 0.200 & -0.117 & 0.1227 & -0.595241483 \\
\hline GIWO & 0.192 & -0.074 & -0.0606 & -0.523564426 \\
\hline $\mathrm{CH}$ & 0.192 & 0.077 & 0.4875 & 0.100269977 \\
\hline HIOF & 0.218 & -0.141 & 1.0474 & 0.695829283 \\
\hline IFTS & 0.134 & 0.203 & -0.7207 & -1.98735352 \\
\hline $\mathrm{HCS}$ & 0.158 & 0.215 & -0.5688 & -0.321369452 \\
\hline$M L$ & 0.136 & 0.359 & 1.1631 & -0.126586857 \\
\hline LDbCP1 & 0.195 & -0.200 & -0.3584 & 1.631805873 \\
\hline $\mathrm{MMH}$ & 0.166 & 0.101 & -0.8151 & 0.390816631 \\
\hline $\mathrm{MHCP}$ & 0.161 & 0.196 & 0.0122 & -0.062988025 \\
\hline MF_CEM & 0.190 & -0.179 & -0.8309 & -0.144986022 \\
\hline MLS & 0.181 & 0.116 & -0.0717 & -0.508597269 \\
\hline MTM1 & 0.213 & -0.124 & 2.0835 & 0.742569806 \\
\hline ECA & 0.167 & 0.197 & 0.0602 & -1.519867419 \\
\hline ICW & 0.211 & -0.088 & 0.5128 & -0.057136114 \\
\hline MWMC & 0.202 & 0.019 & 0.3716 & 0.208014324 \\
\hline$\%$ variance & $62.6 \%$ & $7.1 \%$ & - & - \\
\hline
\end{tabular}


ACTA

AMAZONICA

ROJAS et al. Ontogenetic variation in lowland tapir skulls

Appendix S1. R code for morphometric statistical analysis (PCA, DFA and allometric analysis) in skulls of Tapirus terrestris from Loreto, Peru

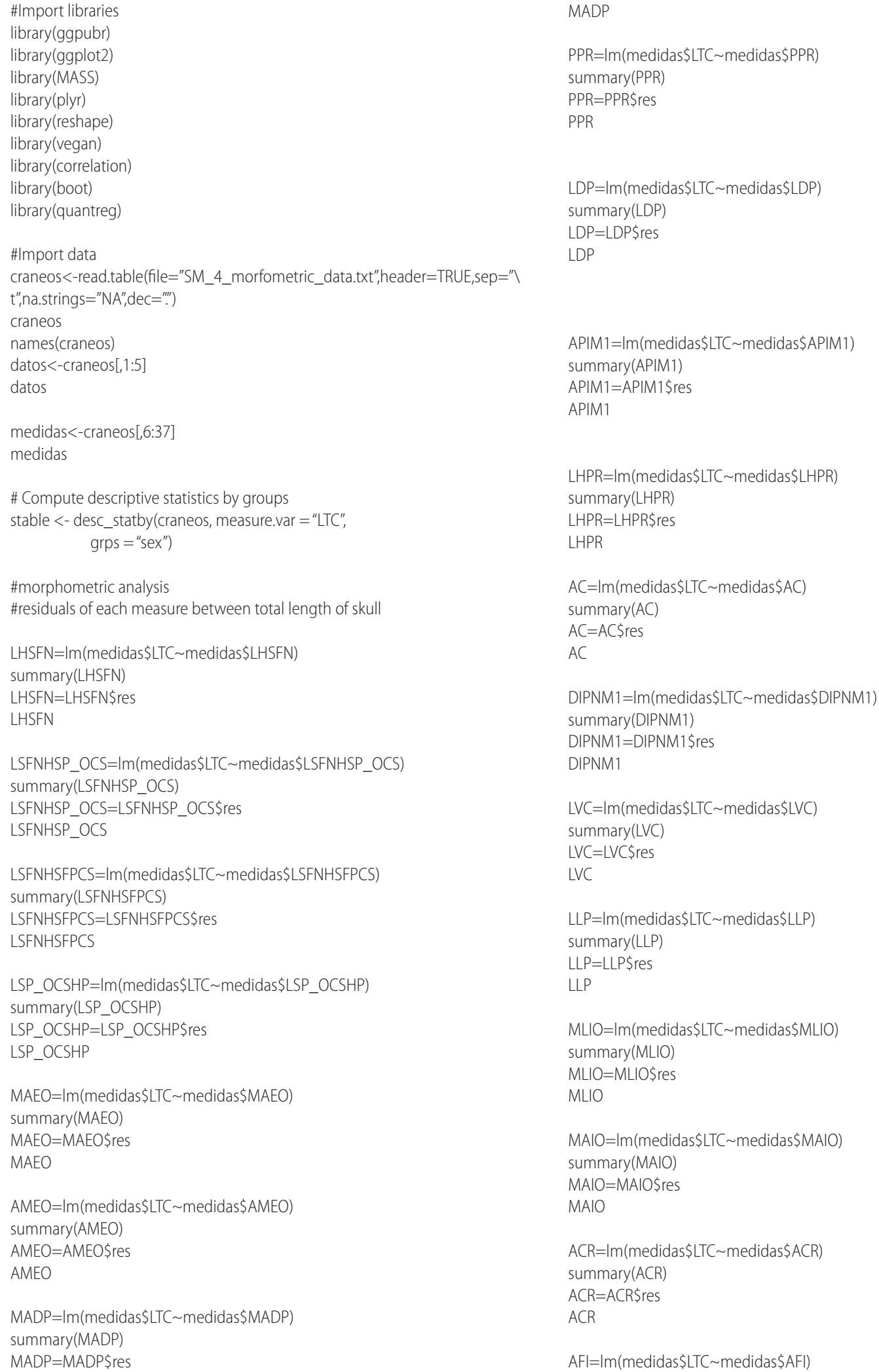

MADP

PPR $=I m$ (medidas $\$$ LTC $\sim$ medidas $\$ P P R$ )

summary(PPR)

$P P R=P P R S$ res

PPR

LDP $=I m$ (medidas $\$$ LTC $\sim$ medidas $\$$ LDP)

summary(LDP)

$L D P=L D P \$ r e s$

LDP

APIM1 $=\mid \mathrm{m}$ (medidas $\$$ LTC $\sim$ medidas $\$$ APIM1)

summary(APIM1)

APIM1=APIM1\$res

APIM1 
ACTA

AMAZONICA

ROJAS et al. Ontogenetic variation in lowland tapir skulls

summary(AFI)

AFI=AFI\$res

AFI

FIPC $=$ Im (medidas $\$$ LTC $\sim$ medidas $\$ F I P C)$

summary $(F \mid P C)$

$\mathrm{FIPC}=\mathrm{FIPC}$ 年es

FIPC

ACC $=\operatorname{Im}$ (medidas $\$$ LTC $\sim$ medidas $\$$ ACC $)$

summary(ACC)

$\mathrm{ACC}=\mathrm{ACC} \$$ res

$\mathrm{ACC}$

LM $=$ Im (medidas $\$$ LTC $\sim$ medidas $\$$ LM)

summary (LM)

$L M=L M \$ r e s$

LM

LDECP1 $=$ Im (medidas $\$$ LTC $\sim$ medidas $\$$ LDECP1)

summary (LDECP1)

LDECP $1=L D E C P 1 \$$ res

LDECP1

AMM $=$ Im(medidas $\$$ LTC $\sim$ medidas $\$$ AMM $)$

summary(AMM)

AMM=AMM\$res

AMM

AMPC $=\operatorname{Im}$ (medidas $\$$ LTC $\sim$ medidas $\$$ AMPC)

summary(AMPC)

$A M P C=A M P C \$$ res

AMPC

FMBCM $=\operatorname{Im}$ (medidas\$LTC $\sim$ medidas $\$$ FMBCM)

summary(FMBCM)

FMBCM=FMBCM\$res

FMBCM

LMS $=$ Im (medidas $\$$ LTC $\sim$ medidas $\$$ LMS)

summary(LMS)

LMS=LMS\$res

LMS

EMM1 $1=\mid m($ medidas $\$$ LTC $\sim$ medidas $\$$ EMM 1$)$

summary(EMM1)

EMM1=EMM1\$res

EMM1

$\mathrm{ACE}=\mathrm{Im}$ (medidas $\$ \mathrm{LTC} \sim$ medidas $\$$ ACE)

summary(ACE)

$\mathrm{ACE}=\mathrm{ACE} \$$ res

ACE

$\mathrm{ACl}=\mathrm{Im}$ (medidas $\$ \mathrm{LTC} \sim$ medidas $\$ \mathrm{ACl})$

summary $(\mathrm{ACl})$

$\mathrm{ACl}=\mathrm{ACl}$ res

$\mathrm{ACl}$

AMCM $=$ Im(medidas $\$$ LTC $\sim$ medidas $\$$ AMCM)

summary $(\mathrm{ACl})$

AMCM=AMCM\$res

AMCM

\#residuals cbind

union.de.residuos<-cbind(LHSFN,LSFNHSP_OCS,LSFNHSFPCS,LSP_
OCSHP,MAEO,

union.de.residuos

AMEO,MADP,PPR,LDP,APIM1,LHPR,AC,DIPNM1,LVC, LLP,MLIO,MAIO,ACR,AFI,FIPC,ACC,LM,LDECP1,AMM, AMPC,FMBCM,LMS,EMM1, ACE,ACI,AMCM)

pca $<-$ prcomp ((union.de.residuos), ret $x=T$, center $=T$, scale $=T$ )

pca

summary(pca)

\#PC1+PC2 Differences between ages and sex

summary $(\operatorname{lm}($ pca\$x[,1:2] craneos\$clase+craneos\$sex $))$

\#PCA graphic by sex

scores<-data.frame(craneos\$sex,pca\$x[,1:2])

scores

issp06 $<-$ na.omit(scores)

issp06 $<-$ droplevels(scores)

issp06

$\mathrm{df}<-$ scores

df

find_hull <- function(issp06) issp06[chull(issp06\$PC1, issp06\$PC2), ]

find_hull

hulls $<-$ ddply(df,"craneos.sex", find_hull)

hulls

fig2 <- ggplot(data=issp06, aes(PC1, PC2, colour=craneos.sex, shape=craneos sex)) +

geom_point (size $=5)+$

$\operatorname{labs}(\mathrm{x}=$ "PC1 62.6\%", $\mathrm{y}=$ "PC2 7.1\%")

fig2

\# Convex hulls

fig 2 b $<-$ fig $2+$ geom_polygon(data=hulls, alpha $=.001)$

fig $2 b$

\#PCA graphic by age

scores<-data.frame(craneos\$clase,pca\$x[,1:2])

scores

issp06 <- na.omit(scores)

issp06 <- droplevels(scores)

issp06

$\mathrm{df}<-$ scores

df

find_hull <- function(issp06) issp06[chull(issp06\$PC1, issp06\$PC2), ]

find_hull

hulls $<-$ ddply(df, "craneos.clase", find_hull)

hulls

fig2a <- ggplot(data=issp06, aes(PC1, PC2, colour=craneos. clase,

shape $=$ (raneos.clase) $)+$

geom_point(size $=5)+$

labs $(x=$ "PC1 62.6\%", $y=$ "PC2 7.1\%")

fig $2 a$

\# Convex hulls

fig2a $<-$ fig2a + geom_polygon(data=hulls, alpha=.001)

fig2a

figura <- ggarrange(fig $2 b$, fig2a,

labels $=C(" A, ", B ")$,

$\mathrm{ncol}=1$, nrow $=2$ 
ACTA

AMAZONICA

ROJAS et al. Ontogenetic variation in lowland tapir skulls

figura

\#Discriminant Function

\#sex

wine.Ida $<-I d a(d a t o s \$$ sex $\sim$ union.de.residuos)

wine.lda

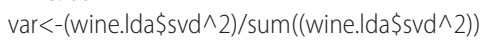

var

write.table(wine.Ida\$scaling, file="Ida_sex.xls", sep=" $\mathrm{t}^{\prime \prime}$ )

wine.lda.values <- predict(wine.lda)

wine.lda.values $\$$ class

Idahist(wine.Ida.values\$x[,1], g = craneos\$sex)

\#age

wine.lda $<-I d a(d a t o s \$ c l a s e \sim u n i o n . d e . r e s i d u o s)$

wine.lda

var<-(wine.Ida\$svd^2)/sum((wine.lda\$svd^2))

var

write.table(wine.Ida\$scaling, file="Ida_age.xls", sep=" $\backslash t^{\prime \prime}$ )

wine.lda.values <- predict(wine.lda)

Idahist(wine.Ida.values\$x[1], g = craneos $\$$ clase)

\#allometric analysis

todos $=\operatorname{Im}$ (medidas $\$$ LTC

medidas\$LHSFN + medidas\$LSFNHSP_OCS +

medidas\$LSFNHSFPCS+medidas\$LSP_OCSHP+medidas\$MAEO+

medidas $\$$ AMEO+medidas $\$ M A D P+$ medidas $\$ P P R+$ medidas $\$$ LDP+

medidas $\$ A P I M 1+$ medidas $\$ L H P R+$ medidas $\$ A C+$ medidas $\$ D I P N M 1+$

medidas\$LVC+medidas\$LLP+medidas\$MLIO+medidas\$MAIO+

medidas $\$ A C R+$ medidas $\$ A F I+$ medidas $\$ F I P C+$ medidas $\$ A C C+$

medidas\$LM+medidas\$LDECP1+medidas\$AMM+medidas $\$ A M P C+$

medidas\$FMBCM+medidas\$LMS+medidas\$EMM1+medidas\$ACE+

medidas $\$$ ACl+medidas $\$$ AMCM)

names(medidas)

coef<-as.matrix(coef(todos))

coef

write.table(intervals, file="intervales.txt", $\left.\operatorname{sep}=" \backslash \mathrm{t}^{\prime \prime}\right)$

intervals<-confint(todos, level=0.90)

intervals

summary(todos)

coeficientes=todos $\$$ coefficients

coeficientes

coeficientes=as.matrix (coeficientes)

write.table(coeficientes, file ="morfo.txt", sep=" $\mathrm{t}^{\prime \prime}$ )

todos\$coefficients

todos

coefplot(todos, intercept=FALSE, group.par=list( $(\mathrm{W}=2$, line.adj $=0.182$ 